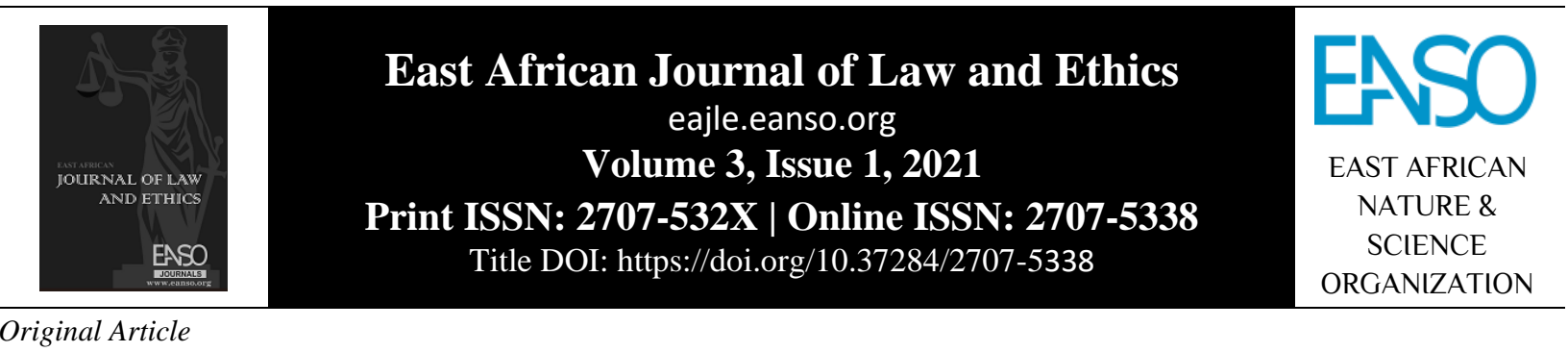

\title{
The Role of Personalism in Eradicating Linguistic Violence
}

\author{
Mark Omorovie Ikeke ${ }^{1 *}$ \\ ${ }^{1}$ Delta State University, PMB 1, Abraka, Nigeria. \\ *Author for Correspondence email: Ikeke7@yahoo.com
}

Article DOI: https://doi.org/10.37284/eajle.3.1.323

\section{Date Published: ABSTRACT}

26 April 2021 Human society is filled with violence. Violence happens not only as physical violence but also as linguistic violence. This has brought pain and torment not

Keywords: only to human bodies but also their minds and hearts. Linguistic violence is

Linguistic Violence, Through Critical,

Hermeneutic, Analytic Methods,

Philosophy,

Personalism. often ignored in society, yet it is a factor that has demeaned human personality, caused wars, genocides, xenophobic attacks, and so forth. Because of the negative consequences of linguistic violence, there is a need to raise awareness of it and how to conquer it. Through critical hermeneutic and analytic methods, the paper examined how linguistic violence can be ameliorated if not totally eradicated through the philosophy of personalism. The central argument of this paper is that the philosophy of personalism which emphasizes the value of the human person and decries all forms of degradation and devaluation of humanity can help in ending linguistic violence. It argues that the human person has absolute value and should not be treated as a thing or tool. One of the best ways to combat negative language is to promote a positive language. This can be achieved through the promotion of the ethical value of personalism. The paper finds that linguistic violence is taking place in Nigeria and there is a need to overcome it. The conclusion of the paper is that the philosophy of personalism can help in curbing linguistic violence. When this is done the entire attendant negative consequences associated with it will be overcome.

\section{APA CITATION}

Ikeke, M. O. (2021). The Role of Personalism in Eradicating Linguistic Violence. East African Journal of Law and Ethics, 3(1), 1-9. https://doi.org/10.37284/eajle.3.1.323

\section{CHICAGO CITATION}

Mark Omorovie Ikeke. 2021. "The Role of Personalism in Eradicating Linguistic Violence". East African Journal of Law and Ethics 3 (1), 1-9. https://doi.org/10.37284/eajle.3.1.323.

1 | This work is licensed under a Creative Commons Attribution 4.0 International License. 
HARVARD CITATION

Ikeke, M. O. (2021) “The Role of Personalism in Eradicating Linguistic Violence”, East African Journal of Law and Ethics, 3(1), pp. 1-9. doi: 10.37284/eajle.3.1.323.

IEEE CITATION

M. O. Ikeke, “The Role of Personalism in Eradicating Linguistic Violence”, EAJLE, vol. 3, no. 1, pp. 1-9, Apr. 2021.

\section{MLA CITATION}

Mark Omorovie Ikeke. "The Role of Personalism in Eradicating Linguistic Violence". East African Journal of Law and Ethics, Vol. 3, no. 1, Apr. 2021, pp. 1-9, doi:10.37284/eajle.3.1.323.

\section{INTRODUCTION}

The world is filled with various forms of violence ranging from religious to political violence, economic to psychological violence, cultural to environmental violence, and so forth. Violence comes in various forms such as warfares, political violence, terrorism, crimes against humanity, genocide, war crimes, etc. Violence can also take place among ethnic groups, nations, non-state actors, and in the form of youth restiveness. Not to be left out are domestic violence and abuse, the violence caused by colonialism, xenophobic attacks, anti-globalization protests, and many others. Within a country like Nigeria, violence has taken place in the form of Boko Haram attacks, militant attacks in the Niger Delta, ethno-religious violence, political vandalism, student riots and protests, herdsmen attacks, kidnapping and political assassinations.

The fact is that the world is filled with violence including a country like Nigeria should not be disputed. Recent violence that has taken place in the world includes but not limited to the civil war in Sudan, violence against migrants crossing the Mediterranean Sea to Europe, the murdering of thousands of people and cultural destruction of artefacts by Islamic State (IS) in Syria, the ongoing civil war in Yemen, various shootings that have taken place in the United States in places like Las Vegas, Orlando Night Club, and the shooting in Sutherland Springs in 2017. The violence that has taken place in Nigeria includes the many suicide attacks by Boko Haram, religious violence in places like Jos, Kano, Oyo; conflicts among ethnic groups such as the Urhobo, Ijaw, Itshekiri in Warri and environs in the past, etc. There has also been a faceoff between the federal army and Movement for the Actualization of the Sovereign State of Biafra (MASSOB), and the violent invasion of places like
Odi in Bayelsa, and Ogidegben in Delta State in the past by federal government forces. These invasions have often caused the violence that has brought about the destruction of human lives and the environment.

Hate speech is also a form of pernicious violence that does grave damage to human societies. Much of the violence in the world and Nigeria has been precipitated by hate speeches and negative propaganda against others. This is where the issue of linguistic violence comes into play. When language and human words are used in a negative and dehumanizing way to cause harm to others, the issue of linguistic violence arises. Linguistic violence is one of the most dangerous forms of violence. It can be subtle and go unnoticed. It is the root of many wars and conflicts in society. If it is not solved, then violence in society cannot be solved. The core argument here is that linguistic violence can be eradicated or curbed by promoting a personalism philosophy that emphasizes the noble value and dignity of every human person. As such, it is the language that promotes the good and wellbeing of the human person that should be promoted not one that degrades or dehumanizes the other person. This argument is pursued by using a critical analytic method to break and dissect the various aspects of the issues involved in the discourse. The values of personalism will also be evaluated and proposed as a way to curb linguistic violence. The keywords that ground this paper are now examined.

\section{Terminologies}

The key terms that ground this paper are role, personalism, eradicating, and linguistic violence. The word, "role" is used here to imply significance and the important function that personalism can play in eradicating linguistic violence. What is the place of personalism in the issue of linguistic violence? What help can it offer in curbing

$2 \mid$ This work is licensed under a Creative Commons Attribution 4.0 International License. 
linguistic violence? This is what is implied by the word "role" here. Personalism, on the other hand, refers to any philosophy that gives emphasis to the human person, highlights the noble value of the human person and argues against any form of depersonalization of the human person or reduction of the human person to non-human things in the universe. It enunciates every human person has value and is precious. There is no place for racism, xenophobia or other beliefs and practices that offends against the human person. Yandell (1998) succinctly summarizes what personalism is by stating that:

Personalism is the thesis that only persons (selfconscious agents) and their states and characteristics exist, and that reality consists of a society of interacting persons. Typically, a personalist will hold that finite persons depend for their existence and continuance on God, who is the Supreme Person, having intelligence and volition. Personalists are usually idealists in metaphysics and construct their theories of knowledge by inference from the data of selfawareness. They tend to be nonutilitarian in ethics and to place ultimate value in the person as a free, self-conscious, moral agent, rather than in either mental states or in a personal states of affairs. Typically, holding that a good God will not allow what has intrinsic value to lose existence, they believe in personal survival of death (par 1)

"Eradicating" means eliminating, curbing, removing and bringing to an end a thing or reality. Within the context here, it means ending linguistic violence. What is linguistic violence? Each word will be examined and them collectively. What is linguistics? The Board of Regents of the University of Arizona (2017) indicates that:

"Linguistics is concerned with the nature of language and communication. It deals both with the study of particular languages and the search for general properties common to all languages or large groups of languages" (par. 3).

For the Regents of the University of California at Santa Cruz (2017), "Each human language is a complex of knowledge and abilities enabling speakers of the language to communicate with each other, to express ideas, hypotheses, emotions, desires, and all the other things that need expressing. Linguistics is the study of these knowledge systems in all their aspects: how is such a knowledge system structured, how is it acquired, how is it used in the production and comprehension of messages, how does it change over time? (par 1). Linguistics is concerned with language and the use of language.

And what is violence? In the words of Galtung (2010):

Violence is any avoidable insult to basic human needs, and, more generally, to sentient life of any kind, defined as that which is capable of suffering pain and can enjoy wellbeing....Violence to human beings hurts and harms body, mind, and spirit (p. 312).

Violence is not limited only to what happens to sentient life but can happen to non-sentient aspects of nature such as rocks, oceans, etc. ObizulikeOsuofia (2013) defines violence as "any act of force or abuse that degrades, reduces or that is physically injurious to the other party" (p. 141). Violence may not cause immediate physical harm but can cause spiritual, psychological and emotional hurts in peoples' minds and hearts, and precipitate a negative memory, and scars.

With the above understanding of language and violence, linguistic violence can now be defined. For Corsevski (2007), it is using hurtful, mean, base, and nasty speech or words in communication. This often can cause physical violence. Msuya (2016) cites various authors such as S. Ross, N. C. Gay, T. P. Kaplan and E. C. Armstrong to show that linguistic violence is the psychological or social use of language to abuse, hurt, offend, demean and denigrate, spread hatred and cause a difference in perceiving the other as inferior, subordinate, and an enemy. In Nazi Germany, Hitler and his followers used language to incite racial violence, abuse, kill, and to hunt out the perceived enemy such as the Jews. Oppressed people all over the world are often victims of linguistic violence as the oppressors often use abusive words and hate speeches against them. People like African Americans and other ethnic minorities, Africans in Apartheid South African, many indigenous peoples under colonialism, etc. have been victims of linguistic violence.

3 | This work is licensed under a Creative Commons Attribution 4.0 International License. 


\section{The Reality, Challenge and Consequences of Linguistic Violence}

The fact that there is linguistic violence in the world cannot be denied. It occurs daily and almost in every society. Think of the fact of the oppression and discrimination that has occurred against women and minorities in society; it is rooted in linguistic violence. Language is used to degrade and devalue the dignity and nobility of women and minorities. In many African communities, words and terms are often used to describe the identity and function of women that show that they are weak, inferior, not to be seen or heard. When there are challenges in marriage such as barrenness and financial troubles, the women are often labelled as witches. They are labelled husband-killers when their husbands die. Abuses are rained on them even by fellow women during the time of widowhood. That a great deal of linguistic violence against women has taken place in the Nigerian society is shown by Adetunji (2010):

Interestingly, we encounter the subordination of women in language use in a commercial bank, a place expected to be gender-sensitive. For example, one of the mission statements of Union Bank, one of the biggest commercial banks in Nigeria "Every worker should do his duty" reflects and gender insensitivity, especially when the pronoun "his" is underlined and thus, foregrounded. This confirms the Bank's presupposition that "his" includes "her". Likewise, in the Nigerian print media, there are still instances of the use of the male pronoun, "he", to identify both male and female referents. For example, in the Daily Sun (edition of July 28, 2009, p. 11), a news item is presented in which a woman is referred to as a "chairman": "Chairman of the Economic and Financial Crimes Commission (EFCC), Mrs. Farida Waziri, has said tough time awaits corrupt public office holders and other categories of fraudsters in the country." Moreover, the use of the tag, (p. 13)

Almost all religions have used words that describe women as inferior to men. In Paul's writing, women are called the weaker sex and seen as if their only function is to bear children. Though there were mighty women in the Judeo-Christian scriptures, the status of women was relegated to the background.
They are to keep silent and be subservient. In much of Islam, women are seen and described as inferior and less than men. They are denied many crucial responsibilities expected of men. Not until recently, women could not drive in Saudi Arabia. In African Traditional Religion, though women have played prominent roles in some African cultures, yet in generality, they are often seen as subservient to men, men are to exercise authority over them and the men often go unquestioned when they abuse and beat their wives. Women are subjected to a great deal of domestic violence and abuse and are often the victims of linguistic violence.

In the world of sport, linguistic violence has also taken place. One of the problems that sport is dealing with is that of racism. Black sportsmen and people of foreign nationalities are often called derogatory names by white players. CGTN America (2015) states the following cases among many others that reveals racism in sport: (1) in March 2015, Chelsea fans sang racist chants and refused to let a black man ahead of them in a train, (2) the Ghanaian player, Kevin Prince Boateng walked out of the pitch with teammates after racist chants against him in January 2013, (3) in 2015, Australian Rugby Union Player Justin Harrison was accused of verbally abusing his opponents' team, (4) exClippers owner Donald Sterling was recorded as making racist remarks about African Americans.

Linguistic violence is a serious problem for society. Linguistic violence in the form of hate speeches has actually caused physical violence. Much of the recent xenophobic attacks against Nigerians and people of other nationalities in South African have been as a result of hate speeches against them. Millions of Jews lost their lives as a result of linguistic violence coming from Adolf Hitler and his supporters. Linguistic violence by Islamic State has influenced some persons to go on shooting and killing persons in France, Britain, the USA, and Denmark.

Another serious consequence of linguistic violence is the inferiority complex. The linguistic violence caused by colonial masters in Africa and the Southern Hemisphere made many Africans and others see themselves as inferior to whites. Some came to doubt their identity, personhood, and value. 
This fact is clearly expressed in authors such as Freire (2010), Freire (1993), and Fanon (1963).

\section{The Philosophy of Personalism}

There are many forms of personalism, and this very fact made Jacques Maritain as cited by Williams and Bengtsson (2016) to opine that there are "a dozen personalist doctrines, which at times have nothing more in common than the word 'person.' Williams and Bengtsson (2016) have also opined that personalism has at its heart the subjectivity of the human person and deeply informed by phenomenology and existentialism. For Williams and Bengtsson (2016),

It emphasizes the significance, uniqueness and inviolability of the person, as well as the person's essentially relational or communitarian dimension. The title "personalism" can therefore legitimately be applied to any school of thought that focuses on the reality of persons and their unique status among beings in general, and personalists normally acknowledge the indirect contributions of a wide range of thinkers throughout the history of philosophy who did not regard themselves as personalists. Personalists believe that the human person should be the ontological and epistemological starting point of philosophical reflection. They are concerned to investigate the experience, the status, and the dignity of the human being as a person, and regard this as the starting point for all subsequent philosophical analysis (par. 2).

According to the New World Encyclopaedia (2015) Personalism is the philosophical belief that affirms the autonomy, value, reality and worth of the human person, as a human person related to others and not simply an individual. The New World Encyclopaedia (2015) affirms that scholars such as Borden Bowne, Emmanuel Mounier, Pope John Paul II, Martin Luther King, Jnr, Jacques Maritain, Gabriel Marcel, and even Kant have all contributed to this philosophical belief, though Kant is not considered a personalist. Since the method of this work is not a historical methodology, the paper does not intend to trace the history of personalism. It will suffice after the above definition to mention the viewpoints of some key personalist philosophers. In his discussion of Personalism, Buford (n.d.) notes that:

Personalism is any philosophy that considers personality the supreme value and the key to the measuring of reality. Its American form took root in the late nineteenth century, flowered in the twentieth century, and continues its life in the twenty-first century. Yet, those roots can be traced to Europe and back through Western philosophy to the Mediterranean basin. However, personalism did not originate exclusively in America, Europe, the Mediterranean basin, or in the West. Personalism thrived in India through the six orthodox schools of Indian philosophy scattered along the Indus River Valley of the Indian subcontinent and developed parallel to Personalism in the West (par. 1).

The above reveals that personalism is not just one monolithic philosophy. It can be found in various cultural traditions with various emphases but all connecting the value of the human person. In his Personalism, Bowne, as cited by Buford (n.d.), argued against materialism, naturalism reductionism, social Darwinism of Herbert Spencer and positivism. For Bowne, a theologian at Boston University in the early $20^{\text {th }}$ century, the human person is the fundamental reality; the person is real and not simply a speck of matter. He clearly affirms that the person has value and is larger than the universe for it is the person that experiences the universe.

The philosopher, Emmanuel Mounier lived from 1905 to 1950 and he advocated deep respect for human rights and human personality. Mounier, according to Omoregbe (2005), avers: "I sin against the human person if I treat my workers as tools" (p. 197). It is unfortunate to note that the language that has been used towards minorities such as women, blacks, etc. through history has been language that sees them as tools, instruments, properties, and things.

In Immanuel Kant's philosophy, the human person is an autonomous rational being, and the human person is not a means to the end of another human person, rather the human person is an end in itself. The human being has dignity and absolute worth. It is unfortunate that as for human beings, Kant did not

5 | This work is licensed under a Creative Commons Attribution 4.0 International License. 
consider Africans and blacks as equal to other human beings such as whites. You can also find personalism thoughts in Mahatma Gandhi. Moniz (1998) relates to Gandhi affirming that the human person is at the centre of social order and the person is willing to sacrifice for the good of others, love and serve others. Gandhi states that the principle of ahimsa (non-violence), the human person seeks not to harm others

John Paul II is certainly a Christian personalism philosopher. He devotes many of his writings and speeches to emphasize the value, dignity and human rights of the human person. It is interesting to note that John Paul II, then Karol Wojtyla as professor of ethics at the Theological Faculty of Cracow and Lublin's Catholic University founded a personalism school (Williams 2004). For Wojtyla, the human person has value and dignity and philosophies such as Hegelian totalitarianism, National Socialism, Marxist Communism should be rejected. Williams (2004) cites Wojtyla saying that: “Indeed, man's dignity is rooted in his rational nature, which separates him from the rest of visible creation and wherein chiefly lies his resemblance to God. No matter what other elements are emphasized- the person $=\mathrm{s}$ freedom, his creativity, his action, his selfconsciousness, his interiority, his sociability, and so forth - they all have their objective base in an intellectual, and thus a spiritual, nature" (p. 176).

Writing of African Personalism, Buford (n.d) states that:

Among African American personalists, the best known was Martin Luther King (1929-1968). King translated personalism into social action by applying it to racism, economic exploitation, and militarism. Following closely its major themes, he emphasized the existence of a personal God, the dignity and sacredness of persons, the existence of an objective moral order and corresponding moral laws, freedom, and moral agency.

King saw every human person and individual as valuable, the subject of fundamental human rights, and equal. Each human person is to be treated as somebody. King saw every human being no matter their colour a child of God and created in God's image. They all have equal dignity and deserve respect for their fundamental human rights.
Arguing on the relevance of Personalism, Mooney (2012) says that:

Personalism contrasts with Marxist materialism and other forms of collectivism in which the individual is subsumed to the communal and the individual has no inherent worth. Personalism, by contrast, argues that a person can never be simply the means to another end, but each person must be treated as an end in and of himself. Liberal individualism too often conflates utility and value, but personalism also rejects the utilitarian idea that a person's utility is the same as his value. Another way of stating that a person's worth is not reducible to the profit she or he makes is expressed when Schmeising quotes Maurin as saying "the foundation of the economy should be the 'person, not profit.'

From the above, some things should be clear about personalism. As Williams (2004) notes: human persons are not to be reduced to non-human persons, the uniqueness of the human person, the interiority and subjectivity of the human person, the selfdetermination of the human person as an acting subject, and the communitarian dimension of the human person.

\section{Eradicating Linguistic Violence through Personalism}

As noted above, at the root of much violence in the world is linguistic violence. If linguistic violence can be eradicated or greatly reduced it will help in ending many forms of violence in the world. Those who often use words or language to abuse or demean others lack a value and respect for the human dignity of others. If you see the other person as different from you, inferior and subordinate to you, and as less a human than you, you are probably going to treat him/her as such. You will use verbal abuse to hurt and hunt that person down. This is precisely what happened in Nazi Germany when Hitler and his followers demean Jews and labelled them with negative names in order to condemn them to the gas chambers.

It also happened in the United States, where African Americans and people of colour were seen as inferior and less human than whites. Terms such as "niger" "ignorant," and monkeys" were used to

6 | This work is licensed under a Creative Commons Attribution 4.0 International License. 
describe them. They were deprived of their fundamental human rights and other entitlements. Not until there was a marked recognition that African Americans were fully humans and equal to whites were they allowed to come into a full community. The schools were then desegregated; they were then allowed to vote, etc. It was thanks to the powerful use of language by such philosophertheologian as Martin Luther King, Jnr in all his speeches and writings that African Americans will gain their human rights. He used words and language as "somebodiness," "beloved community," "children of God" to highlight the dignity and noble value of African Americans and all people of colour. King in his language discriminated against nobody. $\mathrm{He}$ equally highlighted the fact that whites have equal dignity and are human persons. You can contrast the nonviolent language of King with that of Malcolm X, whose language could be tagged as linguistically violent. He used such terms as "snake" to name the white man. His language precipitated violence against the whites, while that of King fostered peace and harmony. In India, Gandhi used language in a non-violent manner to win the independence of his country from the British.

It has been argued that linguistic violence in South Africa has often preceded physical violence against other blacks, such as Nigerians who are not South Africans. When they are perceived as foreigners, intruders, etc., they are then attacked. If the South Africans who attacked other Africans had rooted themselves in the language of "Ubuntu," African brotherhood, and seen fellow Africans as brothers and sisters, they would have likely protected them from violence and harm. Language matters. In Nigeria, hate speeches as happened before the civil war, and in the recent clashes or threats to southerners in the North, or Northerners in the South are precipitated by violent language. White racists and nationalists in the United States have often influenced their members to violently attack others and cause harm as happened in Charlottesville, etc. Racism, ethnicism, "tribalism," and other negative "isms" have to be critiqued for what they are. All human persons share in ontological equality. You are not less human because of the colour of your skin. It is unfortunate to note that you can see elements of racists or sexist's language in the philosophy of Aristotle, Kant, Hegel, etc.

The philosophy of personalism has great value for the human person, every human person. And if one truly values the human rights and dignity of each human person, such a person will shun linguistic violence. Such a person knows that linguistic violence harms the other, and the other deserves respect, not insults or abuses. All human beings share in one common humanity, and as such one happens to all. Gandhi, Jesus, King Nyerere, and Kaunda are all right in perceiving all men and women as belonging to one common brotherhood/sisterhood. Through propagating the values of personalism, people's attitudes and behaviour to others will change from a negative one to a positive one.

The human person is not a thing but a conscious being. Those who see other human persons as less human than them or see them as things often use words to express those beliefs. Actions are often the consequences of beliefs. What people believe about the human person is how they will act. Do you see other people as things and properties and less human than you? That is how you will act towards them. Your words express your beliefs. To act properly towards other persons enhancing their human dignity and nobility, your beliefs must be right. Central to this work is that cultivating personalist beliefs will help in acting to enhance the value and dignity of other persons. Dangerous ideologies such as racism, colonialism, apartheid, ethnicism, all see the other as things and objects to be exploited, rejected and discriminated against. These ideologies are rooted in linguistic violence against the other. For racists the other person outside his race is not a human person and should be seen as a nuisance; for apartheid, the other is a slave and less human, for colonialist, the other is a "black monkey", ignorant and inferior, and for the ethicist, people of other ethnic groups are persons to be discriminated against. That personalism can help in creating a healthy mental mindset that helps to create a positive language to help human persons is clear.

Omoregbe (2005) writing on the contribution of philosophy to national development argues forcefully thus that personalism can help in curbing the depreciation of the value of the human person. 
He reveals that the inviolable dignity of the human person, his inalienable rights and the inescapable moral responsibility of the human person are promoted through personalism. The human person is not an object and is not reducible to nature. Philosophy helps to educate the human mind to appreciate the value of each human person. This being the case by promoting the philosophy of personalism, it can help to curb philosophies, theologies, ideologies, and beliefs about human persons that demean, degrade, and depersonalize them.

If you have a personalism mindset, you are more likely to use words that enhance human dignity than somebody who has a negative mindset and sees others as less human or inferior.

\section{CONCLUSION}

The paper has revealed that linguistic violence is a reality in the world. Linguistic violence is rooted in either hatred against the other or distorted/wrong perception of the other person. It is clear from the paper that a positive humane perception of others will help people to speak words and using language that fosters human dignity, value, nobility, and rights of others. This positive humane mindset about others can be fostered through the philosophy of personalism that highlights the value and centrality of the human person. The human person is not a thing, property or material, and so the person should be honoured and celebrated with positive language.

In all, if a philosophy of personalism is promoted it will help to eradicate linguistic violence. Indeed, as Crosby (2013) noted, personalism calls for extending respects to all humans irrespective of ethnicity, nationality, gender, sex, etc. The argument of this paper has been that when this respect is extended, we will shun linguistic violence and use language that promotes the welfare and well-being of the other.

\section{REFERENCES}

Adetunji, A. (2010). Aspects of linguistic violence to Nigerian women. Language, Society and Culture, 31, 10-17.

Board of Regents of the University of Arizona. (2017). What is linguistics and why study it?
Retrieved on November 10, 2017, from https://linguistics.arizona.edu/content/whatlinguistics-and-why-study-it-0

Buford, T. O. (n.d). Personalism. Retrieved on November 11, 2017, from Internet Encyclopedia of Philosophy, http://www.iep.utm.edu/personal/

CGTN America. (2015). Examples of racism in sports. Retrieved on November 12, 2017, from CGTN

America: https://america.cgtn.com/2015/08/11/examplesof-racism-in-sports

Corsevski, E. W. (1998). The physical side of linguistic violence. Peace Review, 10(4), 513516.

Crosby, J. F. (2013). Extending respect to all human beings: a personalist account. Journal of EastWest Thought, 57-66.

Fanon, F. (1963). Wretched of the Earth. New York: Grove Press.

Freire, P. (1993). Pedagogy of the Oppressed. London: Penguin Books.

Freire, P. (2010). Education for critical consciousness. London: Continuum.

Galtung, J. (2010). Violence. In Nigel, N. J. (Ed), The Oxford International Encyclopedia Of Peace (p. 312-316). Oxford: Oxford University Press.

Mooney, M. A. (2012). What is Personalism? A rectification of individualism and collectivism. Retrieved from November 5, 2017, from https://www.patheos.com/blogs/blackwhiteandg ray/2012/08/what-is-personalism-arectification-of-individualism-and-collectivism/

Msuya, E. A. (2016). Magnitude and Forms of Linguistic Violence against Teachers in Dar Es Salaam Schools: A Gender Comparison. International Journal of Social Science Research, 4 (1), 1995- 213.

New World Encyclopaedia. (2015, April 16). Personalism. Retrieved on November 21, 2017,

8 | This work is licensed under a Creative Commons Attribution 4.0 International License. 
from https://www.newworldencyclopedia.org/e ntry/Personalism.

Obizulike-Osuofia, M. C. (2013). Peace and conflict studies. Akoka, Lagos: Cadmot Educational Associates.

Omoregbe, J. (2005). Knowing Philosophy. Lagos: Joja Educational Research and Publishers Limited.

Regents of the University of California at Santa Cruz. (2017). What is Linguistics? Accessed

Williams, T. D. \& Bengtsson, J. O. (2013). Personalism. In Zalta, E. N. (Ed), The Stanford Encyclopaedia of Philosophy (Summer 2016 Edition). Centre for the Study of Language and Information (CSLI), Stanford University. Retrieved

fromhttps://plato.stanford.edu/archives/sum201 6/entries/personalism/.

Williams, T. D. (2004). What is Thomistic Personalism? Alpha Omega, 7(2), 163-197.

Yandell, K. (1998). Personalism. In The Routledge Encyclopedia of Philosophy. Taylor and Francis.

$9 \mid$ This work is licensed under a Creative Commons Attribution 4.0 International License. 